\title{
Heavy metals contamination of the soil - water - vegetables chain in the Ilfov region
}

\author{
Gabriel Mustățea ${ }^{*}$, Nastasia Belc $^{1}$, Elena Loredana Ungureanu $^{1}$, Radu Lăcătușu ${ }^{2}$, \\ Jana Petre $^{3}$, Augustina Pruteanu ${ }^{4}$ \\ ${ }^{1}$ IBA - National Research and Development Institute for Food Bioresources, Bucharest \\ 2 ICPA - National Research and Development Institute for Soil Science, Agrochemistry and \\ Environment \\ ${ }^{3}$ ECOIND - National Research and Development Institute for Industrial Ecology \\ ${ }^{4}$ INMA - National Institute of Research - Development for Machines and Installations designed to \\ Agriculture and Food Industry, Bucharest
}

\begin{abstract}
Dietary exposure to several heavy metals such as $\mathrm{Cd}, \mathrm{Cr}, \mathrm{Pb}, \mathrm{As}$ represents a risk to human health through the consumption of vegetables. Due to the possible risks for the human body, contamination of soils as well as drinking and irrigation water has been the subject of many researches.

In this study, the analysis of heavy metals content from soil, water and vegetable samples from households in Ilfov County it was carried out.

As a result, no contamination of soil and water with heavy metals was observed.

Cadmium content is above the maximum allowable limit for all analyzed vegetables, excepting cabbage and green onion. Two lettuce samples have an alarmingly high content of lead, the values being even 10 times higher than the maximum admissible limit of $0.3 \mathrm{mg} / \mathrm{kg}$. The high values obtained for chromium content in lettuce and radish samples raise serious questions about possible contamination. Arsenic content values ranged between 0.87 and $7.69 \mathrm{mg} / \mathrm{kg}$, which also represents high values.

Based on the transfer factor (TF) calculated the strongest accumulation of the metals was in lettuce.
\end{abstract}

Key words: Heavy metals, contamination, soil, water, vegetables

\section{Introduction}

Ilfov County is the smallest county in Romania with a total area of 158.328 hectares and is located in the Arges, Ialomita and Mostistea river basins. This county surrounds Bucharest as a ring. On the territory of this county there is a significant industrial and economic activity with a very good evolution. Representative industries of this county are: the food industry, tobacco processing, leather and footwear, paper and cardboard, rubber and plastics processing. The food, beverage and tobacco industries account for $72.5 \%$ of the total value of the county's total production.

\footnotetext{
${ }^{*}$ Corresponding author: gabi.mustatea@bioresurse.ro
} 
In the last 20 years there has been a socio-economic development of the county in an accelerated pace. This development, besides the positive aspects, also presents the disadvantage caused by the increase of sources of anthropogenic pollution of the environment.

There are many studies regarding the accumulation and origin of heavy metals in soil and the potential ecological hazards associated with this process [1-3]. Researches had attracted attention to the effects of heavy metals on human health. Among many toxic elements, lead, arsenic, and cadmium are considered to be potential carcinogens and are associated with the development of several diseases, especially cardiovascular, kidney, nervous system, blood, and bone diseases [4-8].

Heavy metals enter soil through a variety of sources, including include urban, industrial aerosols created by combustion of fuels, metal smelting, and other industrial activities. Other sources of soil contamination of heavy metals are excessive dose of pesticides, micronutrient fertilizers, and manures such as sewage sludge $[9,10]$.

Heavy metals can become a health risk via consumption of contaminated vegetables, fruits and drinking water. Vegetables are a necessary component of the human diet, providing a source of essential nutrients, antioxidants, dietary fibers and metabolites.

Absorption and accumulation of heavy metals in vegetables are influenced by many factors, including: concentration of heavy metals in soil, composition and intensity of atmospheric deposition, including precipitations, phase of plant vegetation, irrigation with wastewater, using organic and mineral fertilizers with the load of heavy metals, or application of pesticides [11].

The aim of this paper is to study the contamination with potential carcinogenic heavy metals ( $\mathrm{As}, \mathrm{Pb}, \mathrm{Cd}$ and $\mathrm{Cr}$ ) in soil - water - vegetables chain in the Ilfov region.

\section{Materials and methods}

This study aim was to investigate the degree of contamination by carcinogenic and toxic substances (heavy metals) of the water used for watering crops, of the soil of agricultural use as well as of the grown vegetables in some households from Ilfov County (Copaceni, Jilava, Berceni, Glina).

\subsection{Water samples}

The water samples collected were representative samples of the water quality at the time of sampling and the sampling site. Six samples of water from the wells of some households from the above mentioned places were analyzed.

Determination of heavy metals in water was done by induction coupled atomic emission spectroscopy (ICP-OES) according to SR EN ISO 11885:2009 [12]. Water samples were mineralized in acidic medium to eliminate interference and then were analyzed by ICPOES.

\subsection{Soil samples}

Regarding soil analysis, 11 soil samples from the upper horizon $(0-20 \mathrm{~cm})$ of agricultural soils (vegetables) from the places above mentioned above were collected (Fig. $1)$. 

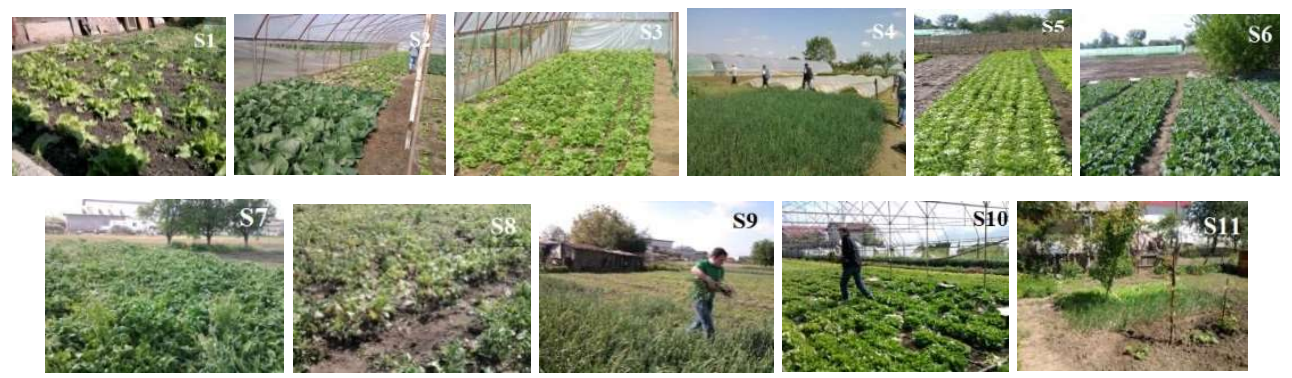

Fig. 1. Places where soil and vegetables samples were collected

Thus, was analyzed the total content of chromium $(\mathrm{Cr})$, cadmium $(\mathrm{Cd})$, lead $(\mathrm{Pb})$ and arsenic (As) in the hydrochloric acid solution obtained after solubilizing the residue resulting from the melting of soil samples with a mixture of perchloric acid $\left(\mathrm{HClO}_{4}\right)$ and nitric acid $\left(\mathrm{HNO}_{3}\right)($ Milestone Digestor Method; SR ISO 11047: 1999 [13]).

\subsection{Vegetable samples}

11 samples of vegetables (lettuce -4 samples, green onion -2 samples, cabbage -2 samples, spinach -1 sample, radish -2 samples) corresponding to the 11 soil samples listed above were harvested and analyzed (Fig. 2).
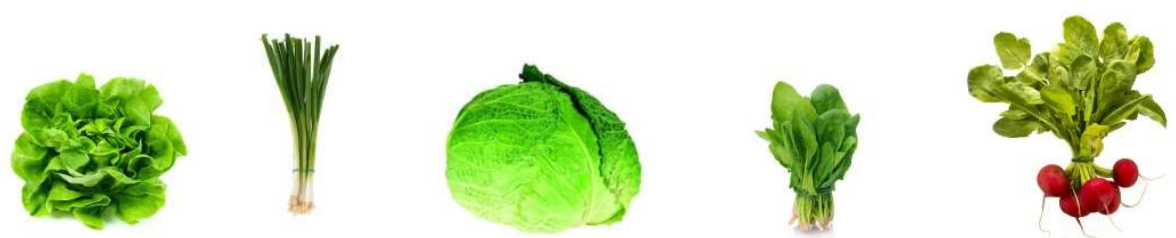

Fig. 2. Analyzed vegetables samples

\subsection{Heavy metals analysis of vegetable samples}

Analysis of the heavy metal content involves two phases: preparation of the samples and proper dosing by atomic absorption spectrometry. Sample preparation was carried out by microwave mineralization according to SR EN 14084: 2003 [14] using a Berghoff MWS-2 microwave oven. The mineralization process was carried out according to the program described below:

Step $1-145^{\circ} \mathrm{C}-10$ minutes $-80 \%$ power;

Step $2-160{ }^{\circ} \mathrm{C}-10$ minutes $-80 \%$ power;

Step $1-190{ }^{\circ} \mathrm{C}-20$ minutes $-80 \%$ power;

The content of lead $(\mathrm{Pb})$, cadmium $(\mathrm{Cd})$, total chromium $(\mathrm{Cr})$ and arsenic (As) was determined using a graphite furnace atomic absorption spectrometer (GF-AAS) AAnalyst 600 - Perkin Elmer, provided with Zeeman background noise correction. 


\section{Results and discussions}

In Table 1 are shown the values of the heavy metals content $(\mathrm{Pb}, \mathrm{Cd}, \mathrm{Cr}, \mathrm{As})$ from the water samples. All water samples were taken from wells in different households, having depths between 7 and $15 \mathrm{~m}$.

Table 1. Heavy metals analysis of water samples

\begin{tabular}{|c|c|c|c|c|c|c|c|}
\hline \multirow{2}{*}{ Code } & \multirow{2}{*}{ Place } & \multirow{2}{*}{ Type } & \multirow{2}{*}{ Appearance } & \multicolumn{4}{|c|}{ Heavy metals content $(\mu \mathrm{g} / \mathrm{L})$} \\
\hline & & & & $\overline{P b}$ & Cd & $\mathrm{Cr}$ & As \\
\hline W1 & Copaceni & $\begin{array}{l}\text { Groundwater (well) } \\
-8 \mathrm{~m} \text { depth }\end{array}$ & $\begin{array}{l}\text { Clear, without } \\
\text { suspended solids }\end{array}$ & $<1$ & $<0.12$ & 1.2 & $<0.2$ \\
\hline $\mathbf{W} 2$ & Copaceni & $\begin{array}{c}\text { Groundwater (well) } \\
-7 \text { m depth }\end{array}$ & $\begin{array}{l}\text { Clear, without } \\
\text { suspended solids }\end{array}$ & $<1$ & $<0.12$ & $<1$ & $<0.2$ \\
\hline W3 & Jilava & $\begin{array}{l}\text { Groundwater (well) } \\
-7 \text { m depth }\end{array}$ & $\begin{array}{l}\text { Clear, without } \\
\text { suspended solids }\end{array}$ & $<1$ & $<0.12$ & $<1$ & $<0.2$ \\
\hline W4 & Berceni & $\begin{array}{l}\text { Groundwater (well) } \\
\quad-7 \text { m depth }\end{array}$ & $\begin{array}{l}\text { Clear, without } \\
\text { suspended solids }\end{array}$ & $<1$ & $<0.12$ & 2.3 & $<0.2$ \\
\hline W5 & Berceni & $\begin{array}{l}\text { Groundwater (well) } \\
-8 \mathrm{~m} \text { depth }\end{array}$ & $\begin{array}{l}\text { Clear, without } \\
\text { suspended solids }\end{array}$ & $<1$ & $<0.12$ & 2.6 & $<0.2$ \\
\hline W6 & Glina & $\begin{array}{l}\text { Groundwater (well) } \\
-15 \mathrm{~m} \text { depth }\end{array}$ & $\begin{array}{l}\text { Clear, without } \\
\text { suspended solids }\end{array}$ & $<1$ & $<0.12$ & $<1$ & $<0.2$ \\
\hline
\end{tabular}

The maximum admissible concentrations $(\mathrm{Pb}-\max 10 \mu \mathrm{g} / \mathrm{L} ; \mathrm{Cd}-\max 5 \mu \mathrm{g} / \mathrm{L} ; \mathrm{Cr}-$ $\max 50 \mu \mathrm{g} / \mathrm{L}$; As - max $10 \mu \mathrm{g} / \mathrm{L}$ ), according to Law no. 458/2002 [15] on the quality of drinking water, updated version, for none of the 4 metals analyzed were exceeded. All the values obtained were extremely low, showing no contamination.

In Table 2 are shown the values of the heavy metals content $(\mathrm{Pb}, \mathrm{Cd}, \mathrm{Cr}, \mathrm{As})$ from the soil samples.

Table 2. Heavy metals analysis of soil samples

\begin{tabular}{|c|c|c|c|c|c|c|c|}
\hline \multirow{2}{*}{ Code } & \multirow{2}{*}{ Place } & \multirow{2}{*}{ Type } & \multirow{2}{*}{ Relief unit } & \multicolumn{4}{|c|}{ Heavy metals content $(\mathrm{mg} / \mathrm{kg})$} \\
\hline & & & & $\mathbf{P b}$ & $\mathrm{Cd}$ & $\mathrm{Cr}$ & As \\
\hline S1 & Copaceni & Aluviosoil & $\begin{array}{l}\text { Arges-Sabar } \\
\text { Meadow }\end{array}$ & 37 & 0.532 & 26 & 2.46 \\
\hline S2 & Copaceni & Aluviosoil & $\begin{array}{l}\text { Arges-Sabar } \\
\text { Meadow }\end{array}$ & 12 & 0.423 & 36 & 3.62 \\
\hline S3 & Copaceni & Aluviosoil & $\begin{array}{l}\text { Arges-Sabar } \\
\text { Meadow }\end{array}$ & 9 & 0.426 & 34 & 3.39 \\
\hline S4 & Copaceni & Aluviosoil & $\begin{array}{l}\text { Arges-Sabar } \\
\text { Meadow }\end{array}$ & 17 & 0.383 & 36 & 3.84 \\
\hline S5 & Jilava & Preluvosoil & Bucharest Plain & 25 & 0.420 & 27 & 2.63 \\
\hline S6 & Jilava & Aluviosoil & Bucharest Plain & 14 & 0.472 & 28 & 3.05 \\
\hline S7 & Berceni & Preluvosoil & Bucharest Plain & 20 & 0.318 & 43 & 3.80 \\
\hline S8 & Berceni & Preluvosoil & Bucharest Plain & 22 & 0.300 & 32 & 3.21 \\
\hline S9 & Berceni & Preluvosoil & Bucharest Plain & 26 & 0.324 & 33 & 3.97 \\
\hline S10 & Berceni & Faeoziom & Bucharest Plain & 19 & 0.420 & 33 & 3.99 \\
\hline S11 & Glina & Cernoziom & Bucharest Plain & 18 & 0.351 & 30 & 3.39 \\
\hline
\end{tabular}

Concerning the heavy metal content, normal values were obtained for $\mathrm{As}, \mathrm{Cd}, \mathrm{Cr}$ and $\mathrm{Pb}$. The lowest values, ranging between 0.300 and $0.532 \mathrm{mg} / \mathrm{kg}$, were obtained for cadmium, while the highest values, ranging between 26 and $43 \mathrm{mg} / \mathrm{kg}$ were obtained for total chromium. The analyzed soils are not polluted with heavy metals. 
11 samples of vegetables: 4 samples of lettuce, 2 samples of green onion, 2 samples of cabbage, 1 sample of spinach and 2 samples of radishes were analyzed (Figure 2). The results obtained for the heavy metals content $(\mathrm{Pb}, \mathrm{Cd}, \mathrm{Cr}$ and $\mathrm{As})$ are presented in Table 3.

Table 3. Heavy metals analysis of vegetable samples

\begin{tabular}{|c|c|c|c|c|c|c|c|c|}
\hline \multirow{2}{*}{ Code } & \multirow{2}{*}{ Place } & \multirow{2}{*}{ Vegetable } & \multicolumn{4}{|c|}{ Heavy metals content (mg/kg) } & \multirow[b]{2}{*}{$\mathrm{Cr}^{*}$} & \multirow[b]{2}{*}{$\mathbf{A s}^{*}$} \\
\hline & & & $\mathbf{P b}$ & MLPb & Cd & MLCd & & \\
\hline S1 & Copaceni & Lettuce & 3.65 & 0.3 & 0.86 & 0.2 & 11.17 & 3.47 \\
\hline $\mathbf{S 2}$ & Copaceni & Cabbage & $<0.002$ & 0.3 & 0.20 & 0.2 & 1.11 & 4.68 \\
\hline S3 & Copaceni & Lettuce & $<0.002$ & 0.3 & 1.92 & 0.2 & $<0.0013$ & 3.22 \\
\hline S4 & Copaceni & Green onion & $<0.002$ & 0.1 & $<0.0002$ & 0.2 & $<0.0013$ & 3.59 \\
\hline S5 & Jilava & Lettuce & $<0.002$ & 0.3 & 1.350 & 0.2 & 9.75 & 7.69 \\
\hline S6 & Jilava & Cabbage & $<0.002$ & 0.3 & $<0.0002$ & 0.2 & $<0.0013$ & 0.87 \\
\hline S7 & Berceni & Spinach & $<0.002$ & 0.3 & 1.66 & 0.2 & 2.27 & 1.70 \\
\hline S8 & Berceni & Radishes & $<0.002$ & 0.1 & 0.26 & 0.05 & 7.70 & 1.32 \\
\hline S9 & Berceni & Green onion & $<0.002$ & 0.1 & $<0.0002$ & 0.2 & 0.74 & 2.64 \\
\hline S10 & Berceni & Lettuce & 10.05 & 0.3 & 0.65 & 0.2 & 60.79 & 5.39 \\
\hline S11 & Glina & Radishes & $<0.002$ & 0.1 & 0.11 & 0.05 & 18.74 & 0.88 \\
\hline
\end{tabular}

The lead content in green onion, radishes, cabbage and spinach samples are extremely low, well below the maximum permitted level laid down in Regulation (EU) no. 1881/2006 [16]. Two lettuce samples (S1 and S10) showed extremely high lead content, exceeding the maximum permitted level laid down in Regulation (EU) no. 1881/2006.

Regarding cadmium content, excepting green onion and cabbage samples, all other recorded values exceed the maximum permitted level laid down in Regulation (EU) no. $1881 / 2006$.

Despite the fact that there is no maximum limit for chromium, the extremely high values recorded for lettuce and radish samples raise serious questions about possible contamination.

Arsenic content values ranged between $0.87 \mathrm{mg} / \mathrm{kg}$ and $7.69 \mathrm{mg} / \mathrm{kg}$. For this element there are no maximum limits.

The plants ability to take up the metals from soil was measured by the ratio between the concentration of element in plant and in soil, representing the biological absorption coefficient $(\mathrm{BAC})$ or the transfer factor $(\mathrm{TF})[17,18]$. TFs for each sample and each element are presented in Table 4.

Table 4. Transfer factors (TFs) for each heavy metal

\begin{tabular}{ccccc}
\hline \multirow{2}{*}{ Type } & \multicolumn{4}{c}{ Transfer factor (TF) } \\
\cline { 2 - 5 } & TF $_{\text {Pb }}$ & TF $_{\text {Cd }}$ & TF $_{\text {Cr }}$ & TF As $^{\text {Lettuce }}$ \\
Lettuce & 0.1 & $\mathbf{1 . 6 2}$ & $\mathbf{0 . 4 3}$ & $\mathbf{1 . 4 1}$ \\
Lettuce & 0 & $\mathbf{4 . 5 1}$ & 0 & $\mathbf{0 . 9 5}$ \\
Lettuce & 0 & $\mathbf{3 . 2 1}$ & $\mathbf{0 . 3 6}$ & $\mathbf{2 . 9 2}$ \\
\hline Cabbage & $\mathbf{0 . 5 3}$ & $\mathbf{1 . 5 5}$ & $\mathbf{1 . 8 4}$ & $\mathbf{1 . 3 5}$ \\
Cabbage & 0 & $\mathbf{0 . 4 7}$ & 0.03 & $\mathbf{1 . 2 9}$ \\
\hline Green onion & 0 & 0 & 0 & 0.29 \\
Green onion & 0 & 0 & 0 & $\mathbf{0 . 9 3}$ \\
\hline Spinach & 0 & 0 & 0.02 & $\mathbf{0 . 6 6}$ \\
\hline Radishes & 0 & $\mathbf{5 . 2 2}$ & 0.05 & $\mathbf{0 . 4 5}$ \\
Radishes & 0 & $\mathbf{0 . 8 7}$ & 0.24 & $\mathbf{0 . 4 1}$ \\
\hline
\end{tabular}


The higher transfer factor of heavy metal indicates the stronger accumulation of the respective metal by that vegetable. A transfer factor of 0.1 indicates that plant is excluding the element from its tissues [19]. The greater the transfer factor value than 0.50 , the greater the chances of vegetables for metal contamination by anthropogenic activities will be and so the need for environmental monitoring of the area will be required [20]. Analyzing results it can be observed that the strongest accumulation of the metals is in lettuce.

\section{Conclusions}

The study shows the possible contamination with heavy metals of water, soil and vegetables samples collected from different places in Ilfov County.

Regarding water samples analyzed, no exceedances of the maximum admissible limits for any of the 4 metals analyzed were recorded.

For the soil samples, normal values were obtained for $\mathrm{As}, \mathrm{Cd}, \mathrm{Cr}$ and $\mathrm{Pb}$, showing no contamination.

Excepting cabbage and green onion samples, cadmium content is above the maximum allowable limit for all other vegetables. Two lettuce samples have an alarmingly high content of lead, the values being even 10 times higher than the maximum admissible limit. Also, the strongest accumulation of the metals is observed in lettuce. Despite the fact that there is no maximum limit for chromium, the extremely high values recorded for lettuce and radish samples raise serious questions about possible contamination. Arsenic content values ranged between $0.87 \mathrm{mg} / \mathrm{kg}$ and $7.69 \mathrm{mg} / \mathrm{kg}$. For this element there are no maximum admissible limits.

\section{Acknowledgement}

This work was supported by Ministry of Agriculture and Rural Development through project ADER 8.1.4.

\section{References}

1. H. Ha, J.R. Olson, L. Bian, et al., Analysis of heavy metal sources in soil using kriging interpolation on principal components. Environ Sci \& Technol 48, 4999-5007 (2014).

2. F. Li, J.H. Huang, G.N. Zeng, et al., Spatial risk assessment and sources identification of heavy metals in surface sediments from the Dongting Lake, Middle China. J Geochem Explor 132, 75-83 (2013).

3. J. H. Huang, F. Li, G.M. Zeng, et al., Integrating hierarchical bioavailability and population distribution into potential ecorisk assessment of heavy metals in road dust: A case study in Xiandao District, Changsha city, China. Sci Total Environ 541, 969976 (2016).

4. A.K. Krishna, K.R. Mohan, Distribution, correlation, ecological and health risk assessment of heavy metal contamination in surface soils around an industrial area, Hyderabad, India. Environ Earth Sci 75 (2016).

5. F. Noli, P. Tsamos, Concentration of heavy metals and trace elements in soils, waters and vegetables and assessment of health risk in the vicinity of a lignite fired power plant. Sci Total Environ 563, 377-385 (2016).

6. S. Izhar, A. Goel, A. Chakraborty, et al., Annual trends in occurrence of submicron particles in ambient air and health risk posed by particle bound metals. Chemosphere 146, 582-590 (2016).

7. S.Z. Cao, X.L. Duan, X.G. Zhao, et al., Health risks of children's cumulative and aggregative exposure to metals and metalloids in a typical urban environment in China. Chemosphere 147, 404-411 (2016). 
8. L. Jarup, Hazards of heavy metal contamination. Brit Med Bull 68, 167 (2003).

9. S. Singh, M. Kumar, Heavy Metal Load of Soil, Water and Vegetables in Peri-Urban Delhi. Environ. Monitor. Assess. 120(1-3), 79-91 (2006).

10. B. Arti, S. ShivDhar, K. Amit, Heavy Metal Contamination of Soil, Irrigation Water and Vegetables in Peri-Urban Agricultural Areas and Markets of Delhi, Water Environment Research 87(11), 2027-2034 (2015).

11. R. Lacatusu, A. R. Lacatusu, Vegetable and fruits quality within heavy metals polluted areas in Romania, Carpth. J. of Earth and Environmental Sciences 3(2), 115-129 (2008).

12. SR EN ISO 11885:2009. Water quality - Determination of selected elements by inductively coupled plasma optical emission spectrometry (ICP-OES).

13. SR ISO 11047:1999. Soil quality - Determination of cadmium, chromium, cobalt, copper, lead, manganese, nickel and zinc - Flame and electrothermal atomic absorption spectrometric methods.

14. SR EN 14084:2003. Foodstuffs. Determination of trace elements. Determination of lead, cadmium, zinc, copper and iron by atomic absorption spectrometry (AAS) after microwave digestion.

15. Law no. $458 / 2002$ on the quality of drinking water.

16. Commission Regulation (EC) No 1881/2006 of 19 December 2006 setting maximum levels for certain contaminants in foodstuffs.

17. K. Khan, Y. Lu, H. Khan, M. Ishtiaq, S. Khan, M. Waqas, et al., Heavy metals in agricultural soils and crops and their health risks in Swat District, northern Pakistan.Food Chem. Toxicol. 58, 449-458 (2013).

18. Y.N Jolly, A. Islam, S. Akbar, Transfer of Metals from Soil to Vegetables and Possible Health Risk Assessment 2, 385 (2013).

19. M. Thornton, E. Farago, Geochemistry of Arsenic.In: C. O. Abernathy, R. L. Calderon and W. R. Chappell, Editors, Arsenic, Exposure and Health Effects, Chapman \& Hall, London, pp: 27 (1997).

20. D. Sponza, N. Karaoglu, Environmental geochemistry and pollution studies of Aliaga metal industry district. Environ. Int. 27, 541-553 (2002). 